\title{
Social Protection and Support for Vulnerable Categories in Albania
}

\author{
Selema Allamani (Dushku)
}

PhD Cand., University of Tirana, Albania, Faculty of Social Sciences, Department of Social and Policy Work selema_i@yahoo.com

Doi:10.5901/mjss.2015.v6n2s5p393

\begin{abstract}
Abtract
One of the most sensitive areas faced by the Albanian society in the period of transition from a centralized economy to the path of free market economy, has been the construction of a modern system of social protection. This article aims to present social protection system in Albania, focused on their distribution especially to the third age and gender differences. The methodology used is qualitative research based on a systematic analysis of the literature. Are analyzing social protection schemes and legal aspect which is based on, referring to the latest official data. The study arrives in two main conclusions. First, due to the global financial crisis and economic growth slowdown, there was an overall increase in poverty, which constitutes a challenge for the reform of social protection scheme for our country. Second, it appears that older women face to more difficulties due to gender policies not right to social protection scheme.
\end{abstract}

Keywords: social protection; poverty; third age; gender differences

\section{Introduction}

Social services are what they expected from a country where through legislation and responsible institutions, as a regulator of welfare in complexity, to help all its citizens.

From a worldwide perspective, the European Union (EU) is clearly a model of social protection. Unemployment, poor health, invalidity, family situations and old age are some of the risks which these systems were created to deal with. The systems also guarantee access to several services that are vital to the preservation of human dignity.

One of the most sensitive areas faced by the Albanian society in the period of transition from a centralized economy to the path of free market economy, in the way of the rule of law, has been the provision of freedom, economic rights and social skills, the right of private property, employment, housing, health, education, and building a modern system of social protection that guarantees the individual member and the families that fall into poverty, financial support to meet basic living needs and services vulnerable groups, in order to include them in social life.

Albania as a country that adheres to be part of a European Community legislation did already enjoys the support through social services for vulnerable category / in need? A enjoys its structures protective institutions to meet the needs for persons with special needs belonging to vulnerable groups? In its development policy or is the focus of the third age, as a target group with special needs?

*** Article 151 of the Treaty on the functioning of the EU (ex Article 136 TEC) names proper social protection and improved living and working conditions among the objectives of the Union and the Member States. Article 153 (TFEU) states that the Union shall support and complement the activities of the Member States concerning, inter alia, social security and social protection of workers. Social protection in the strict sense usually means social security, while social protection in a broad sense includes social security among other social rights of the citizens. In fact, under the heading "solidarity", the Charter of Fundamental Rights of the European Union mentions several rights, such as: the workers' right to information and consultation within the undertaking; the protection in the event of unjustified dismissal; fair and just working conditions; protection of young people at work; and, of course, social security and social assistance.

Concerning this subject, namely social protection in the strict sense, the Charter of Fundamental Rights declares that the Union recognises and respects the entitlement to social security benefits and social services providing protection in cases such as maternity, illness, industrial accidents, dependency or old age, and in the case of loss of employment, in accordance with the rules laid down by European law and national laws and practices.

\section{Analysis}

The methodology used is qualitative research based on a systematic analysis of the literature. With the progressive 
ageing of Europe's population, the problems of retirement and post-retirement become increasingly acute and require cooperation between Member States. In a Resolution on flexible retirement arrangements the Council wants older people to continue to play an active part in society and maintain a link with the labour market. It emphasises that a flexible retirement policy could constitute a rational response to changing demographic patterns and to labour-market changes, but that flexible retirement arrangements are a matter for each Member State, bearing in mind the principle of subsidiary.

\subsection{Types of social protection}

Social assistance: Social assistance is direct, regular and predictable cash or in-kind resources transfers to poor and vulnerable individuals or households (Arnold et al. , 2011: 91). It is usually provided by the state and financed by national taxes (Barrientos, 2010). Support from donors is also important in lower income contexts. Transfers are non-contributory, i. e. the full amount is paid by the provider. Some are targeted based on categories of vulnerability, and some are targeted broadly to low-income groups. This is the primary form of social protection available in most developing countries (Barrientos, 2010).

Cash transfers: are direct, regular and predictable transfers that raise and smooth incomes to reduce poverty and vulnerability (Arnold et al. , 2011: 2). Unconditional Cash Transfers (UCTs) are for the beneficiary to decide how to spend. Conditional Cash Transfers (CCTs) are given with the requirement that the beneficiary meets certain conditions - often related to human capital development, such as visiting a health clinic or ensuring children go to school.

Social pensions: are state pensions, a form of cash transfer targeted by age. Pensions are the most common social protection tool, with the widest global coverage and often highest national spend.

In-kind transfers: are economic and livelihood asset transfers to households, facilitating income generation. They tend to be larger, one-off transfers but can also be smaller, regular transfers, such as food transfers. They tend to take an integrated approach, linking the transfer with skills training and other activities (Holmes \& Jones, 2013: 65).

\subsection{Legislation}

The Constitution of the Republic of Albania in its fourth chapter, establishes and develops in 10 separate articles "Freedoms and rights, economic, social and cultural rights" of individuals.

Thus, in its Article 52/2 provides that: "Everyone, who remains without work for reasons independent of his will and has no other means, is entitled to assistance under the conditions provided for by law".

In its Article 59 stipulates that ". . . the State, within its constitutional powers and means at its disposal, to supplement private initiative and responsibility, aims to: a) employment under suitable conditions for all persons able to work; b) meet the needs of citizens for housing; c) the highest standard of health, physical and mental potential; d) education and qualification according to ability of children and youth, and unemployed persons; e) care and help for the elderly, orphans and the disabled; f) health rehabilitation, specialized education and integration in society of disabled people, as well as continual improvement of their living conditions. "

\subsection{The legal basis for the elderly in Albania}

In the Albanian legislation, the standard services for the elderly are used as an instrument for insurance and maintaining the quality of services and ensuring that the rights of the elderly will be applied according to the Albanian Constitution, the Political Declaration and the International Action Plan for Aging, Madrid 2002, the European Social Cart (revised) and the recommendation of the European Council. In fact these standards regulate the issue of the elderly through the law $\mathrm{nr}$. 9355, date 10. 3. 2005 "For the help and social services (revised), the regulations "For the standard services and social care for the elderly in the centers for the elderly" and "For standard services and social care for the elderly in the day centers". We should emphasize that the law "For help and social services", does not regulate in a specific way all issues that regard the elderly. In the meantime it is seen as necessary from the Albanian Government the application of the standards while placing rules for the quality of the services, which are compulsory for all service providers in the public institutions and other services founded by the NGO sector, and for the private providers as well. These standards are supported in the package of The General Standards of Services, which is approved with a decision by the Ministers' council and are helping governmental structures in fulfilling the new functions such as: fulfilling of the social needs of a community, decision making for improving the services, securing the necessary funding, contracting the service providers etc. These legal initiatives regarding the elderly should not contradict the obligations deriving from the declaration of the human rights and should be harmonized with the International Action Plan for the Aging and other international 
instruments (the Ministry for the Social Issues and Equal Chances).

\subsection{Importance of demographic ageing}

Demographic changes will lead to an unprecedented number of the elderly in the whole world and they will be directly affected by age discrimination. Therefore it is important to increase the pressure on governments and on the society as a whole to respond to this phenomenon. The strengthening of the rights of the elderly is the only proper respond. Even though the governments will implement the development of a new UN cart of declaration, without the elderly advocacy, reach the support without the advocacy. A key role, in order for this to happen, has the civil society organizations, which also can request for accountability from governments regarding their decision on this topic. This is the reason why the society needs more active participation from the elderly. Aging of a nation is one of biggest challenges and it sets the requests related to economic and social growth in all countries. In the whole world, the number of the people that are > 60 is increasing and will continue to increase more than other age groups because of the low fertility rates and the increase life expectancy. The group age of 60 plus years is expected to grow from 600 million in the year 2000, to more than 2 billion in 2050 (source: the population section of the department for economy and social issues in the secretariat of the UN for projecting world population). This growth will increase faster in developing countries where the number of elderly is expected to triple in the next 40 years. In 2050 , more than $80 \%$ of the worldwide elderly will live in developing countries. At the same time, the number of the elderly (80 years and above) in the developed countries will increase in the unpredictable proportions. While aging, the elderly have the need for the financial support, for a chance to get a job, in order to be active and to have access in suitable long-term health and social care.

\subsection{The Albanian population structure}

The Albanian population is considered young compared to other countries in Europe, however, now is showing signs of aging. According to the latest report from the institute of statistics (INSTAT) "Projections of population in Albania 20012021", the number of the young people will significantly reduce while the number of the elderly will progressively increase. The actual population in Albania is 2821977 people, according to the 2011 census, with a slightly bigger percentage of the people under 15 years old, around 29. 5 percent, and with a lower percentage of the elderly who are 65 years old with 7. 4 percent, and with the average age of 29 years old. However even though now considered as a "young population" it seems like the population in Albania will age in the next few decades, and this is a consequence of the low birth-rate. The aging is inevitable and will be accompanies with the decreased number of little children, if birth-rates decrease with fast pace. In the 90' the population structure was significantly changed, while introducing phenomenon like migration and the low birth-rate. According to the average population projection by the INSTAT, and based on high birth-rate the population in Albania is expected to reach 3711929 people, and in case of the increased migration and low birth-rate rate it's projected to be 3215753 people. Nevertheless, it is the birth-rate the one factor that has a direct impact in increase or decrease of the aging of a population. Even though now decreasing, the birth-rate rate used to be one of the highest in Europe. In meantime, the future projections who that the present population of all ages and gender ages every year more and more, compared with mortality rates and migration. Albania is a country with the fastest fall in birth-rates in the last few decades and it is projected to fall in the next few decades. In this way, from an average 2. 3 babies being born per woman in 2011, to three times less than 40 years ago, will decrease in 1.4 babies in 2021. This is one of the main reasons of aging population. In meantime, the increase of the life expectancy, as an important demographical coefficient gives positive data for Albania.

\subsection{Urban and rural population in the years 1950-2050}

The population living in urban and rural areas in the group of indicators Rural Development or/and Urban. Generally, developed countries tend to have a higher population in urban areas compared to rural areas. This facilitates access to basic services, such as provision of water, health care or education. Consequently, it can be said that the higher the ratio of urban to the rural population, the higher the welfare of the inhabitants of a country.

The figures show a global trend of relocation of residents of rural areas to urban areas, a trend that applies to our country: 


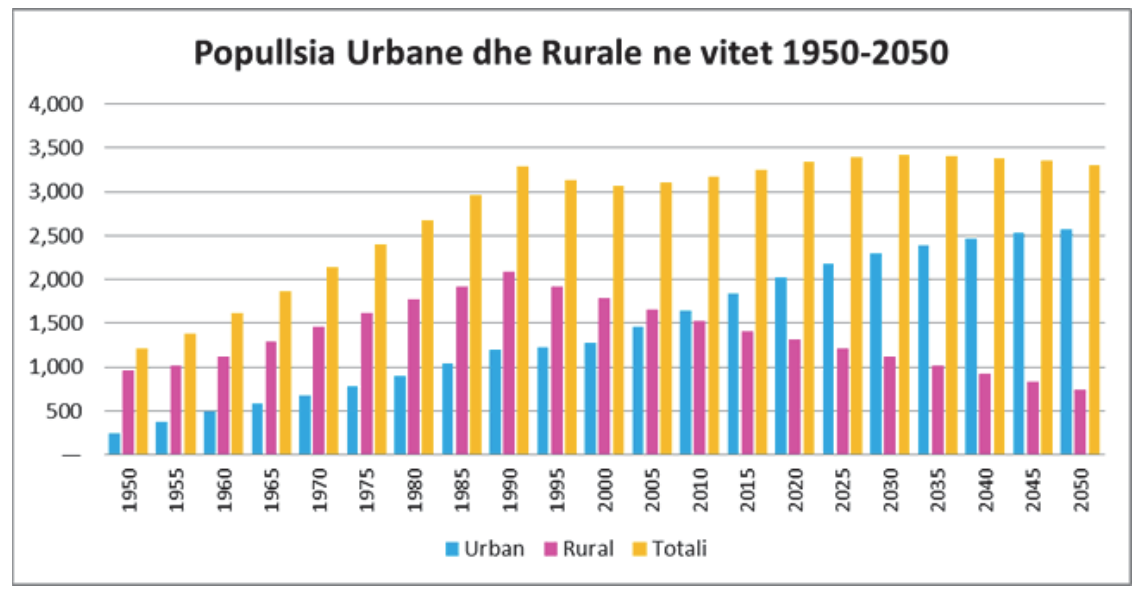

Source of Data: United Nations, Department of Economic and Social Affairs, Population Division (2010). World Urbanization Prospects : The 2009 Revision.

The years 1950-1990 marked an increase with relatively high rates of population, averaging $13 \%$. This pace of growth was reflected in the indicators of population growth of rural and urban areas. However, the growth of urban areas was consistently higher than that of rural areas.

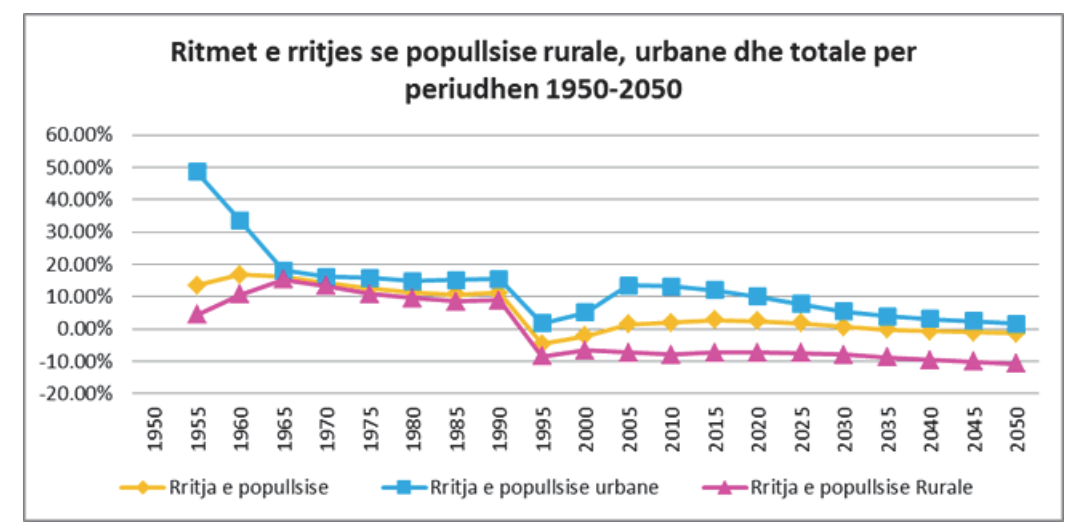

Source of Data: United Nations, Department of Economic and Social Affairs, Population Division (2010). World Urbanization Prospects : The 2009 Revision.

The years 1990-1995 marked significant developments. In this period the total population decreased by 4. 73\%, this low rate compared to previous years, due to two main factors, immigration and fertility reduction. In the same period, the population in rural areas, for the first time marked swing downward, dropping to 8: $45 \%$, while urban areas grew by only 1. $76 \%$. Already people were free to choose whether they wanted to live in the city or in the countryside and their movement was not controlled. The possibility for a more comfortable and still further, higher opportunities for work, making the population in the countryside to fall steadily while the number of city residents were growing.

Even on the projections of the future, there is an exodus from rural areas and predominantly urban population. Starting since 2010, the urban-rural population becomes 50\% to 50\%. N 2020, the proportion of urban population is thought to be $60 \%$ of the total population, and after the 2035 's, the ratio will be about $70 \%$.

\subsection{The comparison between men and women and the third age}

Furthermore, the high number of the women with long life expectancy also presents a challenge for the policymakers. The lack of policy, which addresses these issues, sends lots of elderly toward poverty, and also leads to the non-gratitude of their economical and social contribution, which they offered to their families, communities and to the whole society. Quite often an idea prevailed that in the world there are more women than men. In fact, generally there are only few 
countries where the population of women is higher than $52 \%$ (Switzerland, Armenia, Belarus etc. ). On average, in the world in 2009 49. 59\% of the population was consisted by women. In EU this indicator reached 51. 16\%. These percentages are similar in Albania as well. In the time period of 1998-2010 the number of women as part of general population varied from 49. 8\% - 5017\%. On average, in our country, this number was 99.99 women to 100 men, in other words it was 1 to 1. In 1998 there was 12. 246 more men than women or $0.8 \%$ more. As time passed, this percentage started to change while the number of women started to grow and in 2004-2005 the difference was 11. 000. After this period, men were the ones presented in higher numbers, and in 2010 in Albania there are 16. 400 men more then women. It is interesting fact that men dominate the numbers throughout all these years in age groups of 0-24 years old and 50-69 years old. Women are in dominance in age groups 25-49 and above 70 years old. The latter is because of the longer life expectancy of women compared to men.

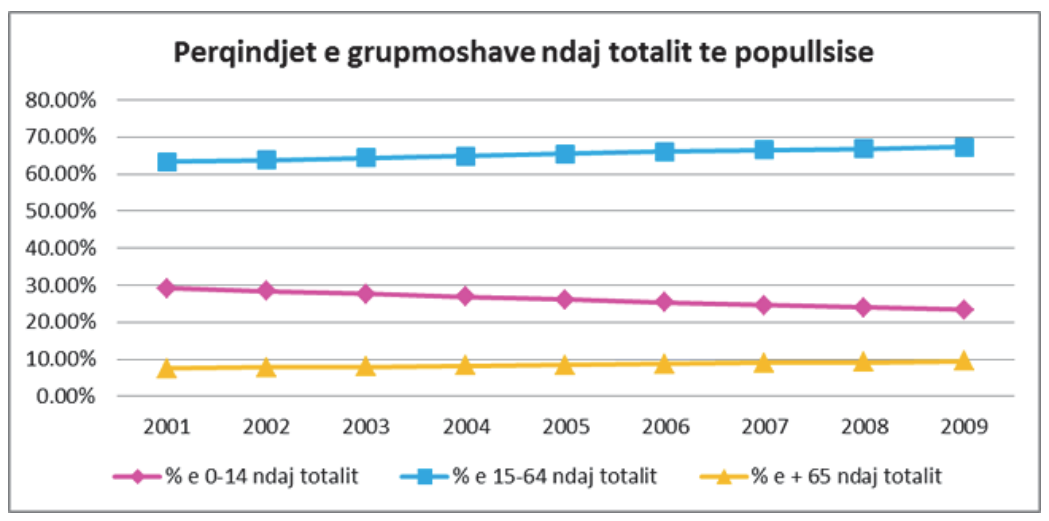

Even though the graph shows negative correlation between two extreme age groups. The percentage taken by the 0-14 years old compared to the total number is decreased on yearly bases while the category of 65 years and above is growing. This fact shows the phenomenon that is slowly becoming evident in our country as well, the nation is getting older. The decrease of birth-rates is expected to become more evident in future generations. In the meantime, the growing number of above 65 years old people should have the state attention for creating preventive social policies and retirement schemes.

\subsection{Older Woman}

Nowadays it is accepted fact that reaching equal gender equality and empowering women is a right thing to do and will have wide effects for women and girls of poor countries in the whole world. We are all aware for the hard conditions in which the older women are, not only in the years of communism and total isolation when they had to worked without receiving any salary and with terrible working conditions, but in the years of transition she also had to face with myriad problems, such as unpaid labour, discrimination in the workplace, in services, retirement etc. in every discussion and all global initiatives was confirmed that the women of the third age are a factor of change, of development and of daily creative solutions, of initiatives and service as a supportive foundation of the families and their communities. Gender inequalities are the different aspects of discrimination with which the older women are facing with and other women also. Women earn less than men. They also quite their careers to take care for their children and other members of the family. In fact, when women are accepted to paid job, it rarely frees her up from other home-related labor and this additional hardship quite often weighs on their health. Knowing that women live longer than men, they have more chances of becoming widows and this is one of the most important factors that relates with poverty, loneliness and isolation. The international plans of action, that are created in different international conferences held by UN, are encouraging countries to reviews their legal human resources in order to eliminate the discrimination between woman and a man. Issues covered here also include the equal access to education of both boys and girls, fighting any kind of gender based discrimination and reducing the negative traditional practices. Many of these preventive interventions on inequality will lay foundations with a sole purpose to lead toward a decent healthy and active aging. The current situation requires a common local strategically partaking and developing of the responsibilities for many decision makers of local issues in Albania, in order for the voice of women to be listened in palling and distributing the services that currently did failed to address the proper needs. 


\subsection{Social Isolation}

As far as the human contacts are concerned, one particular alarming issues are the elderly who are totally isolated (3\%) who do not have any kind of contacts with their families, including cousins or their friends. We should emphasize that still there are strong family relationships and their children and other members of their family are visiting many elderly. Nevertheless, sometimes the elderly are keen to express their family and community's lack of interest for them. Even though strong family ties are still evident in Albania, many of the elderly feel that the "situation is worsened" in the last 1015 years as far as family relationships are concerned, and members of community are less concerned with their problems. Lack of respect is one of the most disappointing issues according to the concepts and feelings that the elderly expressed. Referring to a study done by the Movement of Organizations Supporting a Healthy Ageing - MOSHA, the elderly do not receive the same respect as they were suppose to according to the old Albanian Tradition.

As far as being part of a community is concerned, most of the elderly reported to have difficulties in actively contributing and to be involved in community programs and activities. The elderly are sensing that their voice is not being heard and their opinions are not being taken into consideration.

At the elderly public and non-public residential centres in 2012 there were treated 410 and in daily canters 787 elderly.

During the last year in the elderly residential centres are admitted 67 from which 58 in public institutions and 9 in non-public institutions.

It is noticed that the requests for admitting the elderly in public institutions is growing, and this is happening for the following reasons:

- Increase of the life expectancy in our country,

- The growing phenomenon of small family lifestyle,

- Abandonment of the elderly by their children because of the migration.

- And the improvement of the living conditions in the elderly centres.

Taking into account the increased number of the requests in 2012 for admitting in the elderly residences, there is a need for increasing the institutional capacities and adding new daily services and more alternatives for this target group especially in the community where they live (Yearly Analysis of SHSSH 2014).

\subsection{How are violated the rights of the elderly?}

The elderly rights are violated in different ways, such as:

- The rights of the elderly to be free of any kind of discrimination - the Elderly, women or men, are often denied the access to the services, jobs ore are treated without a respect because of their age and other factors such as gender or disability.

- The rights of the elderly to not be abused - The elderly, women or men are often a subject of verbal, sexual, psychological or financial abuse.

- The rights of the elderly for social security - many of the elderly do not have any kind of financial support such as pension or other forms of social security. The lack of minimum income can lead them and their families into poverty.

- The rights of the elderly for healthcare - the elderly because of their age sometimes cannot receive the needed social healthcare. They can be denied of a treatment or can get limited services.

- The right of the elderly to work- Quite often the elderly are considered as "not capable to get a job" because of their age. This is a violation of human rights, because everyone has a right to a job as long as they consider themselves capable of working. Moreover, the elderly can be asked to quite a job because of reaching the retirement age.

- The rights of the elderly to own real-estate and to inherit wealth - In many parts of the world, the inheritance law denies the rights of women of any age to own or inherit real-estate after the death of their husband. The members of the family often force widows to quit on their right to real-estate, they confiscate it which presents a direct violation of their rights for equal inheritance, managing and selling the wealth.

\subsection{Albania: Trend of Poverty 2002-2005-2008-2012}

As a result of the global financial crisis and overall macroeconomic situation associated with low rates of growth since 
2008, poverty has increased. Part of the population, real per capita monthly consumption of which is under the $4891 \mathrm{ALL}$ (2002 prices), grew by 12. 4\% in 2008 to 14. $3 \%$ in 2012. In previous years, poverty has fallen from $25.4 \%$ in 2002 to 18. 5\% in 2005 and 12. 4\% in 2008 (Figure 1 and Table 1). This means that about 28,896 additional individuals 373. 137 poor individuals in 2008 have fallen into poverty. Extremely poor population, defined as individuals who have difficulty meeting basic food needs, has increased from 1. 2\% in 2008 to 2. 2\% in 2012. Extreme poverty fell from 4. $7 \%$ in 2002 to $3.5 \%$ in $20051.2 \%$ in 2008. In 2012, extreme poverty has risen to 2. $2 \%$ in urban areas and in rural areas 2. $3 \%$

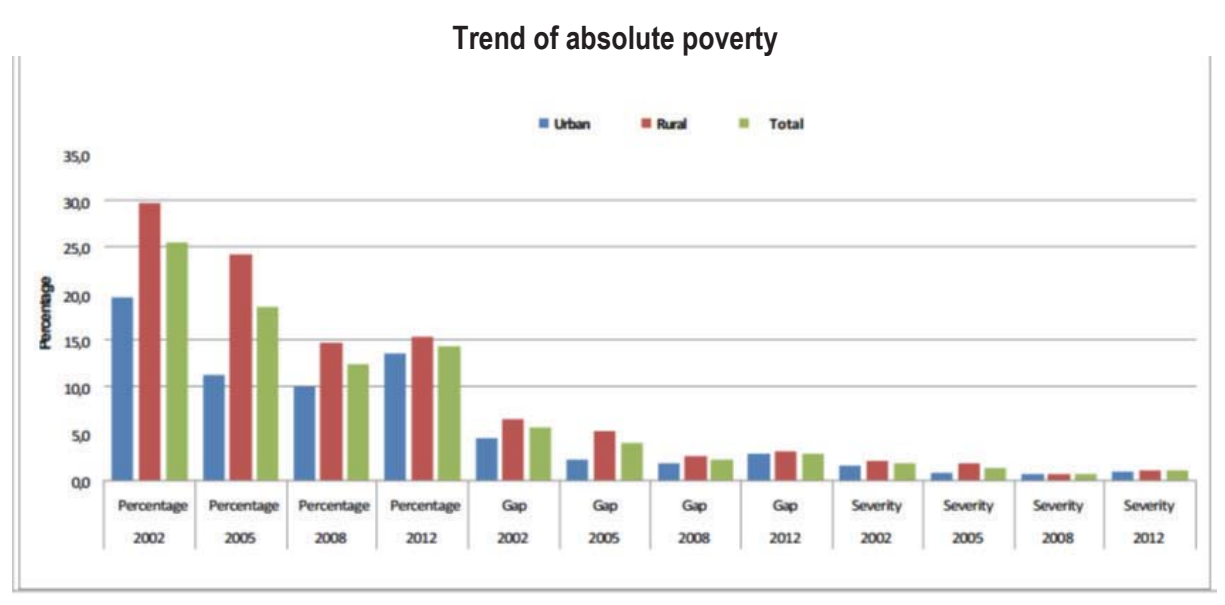

The overall increase in poverty was associated with a higher growth rate of urban poverty. Poverty does not seem to be just a rural phenomenon. Instead, poverty is moved mainly in urban areas. Table 2 shows that, while the rural population in poverty has fallen by about $12 \%$ urban population in poverty has increased by about $37 \%$. The poverty rate in rural areas increased from 14. 6\% in 2008 to $15.3 \%$ in 2012, while urban poverty increased from 10. 1\% to 13. 6\%. Moreover, even within rural areas, the poverty rate is significantly reduced in the Mountain areas. Poverty seems to be a more widespread than in 2008 and is not concentrated in rural mountain areas (Table 1). Other indicators of poverty maintain similar rates of change, as described above, both in urban and rural areas. The poverty gap (depth of poverty) is similar for both urban and rural areas. However, urban areas have had a significant increase in the poverty gap compared to previous years. In rural areas, this figure is 3. $0 \%$, compared with 2. 9\% in urban areas; for rural areas, this indicator has increased by about $15 \%$ compared to 2008 , while the urban areas has grown by about $53 \%$

\subsubsection{Rate and the reduction of poverty in urban and rural areas:}

\begin{tabular}{|c|c|c|c|c|c|c|c|}
\hline & \multicolumn{4}{|c|}{ The number of poor by areas urban/rural } & \multicolumn{3}{|c|}{ Change in poverty } \\
\hline & 2002 & 2005 & 2008 & 2012 & $\begin{array}{l}\% \text { change } \\
2002-2005\end{array}$ & $\begin{array}{l}\% \text { change } \\
2005-2008\end{array}$ & $\begin{array}{l}\% \text { change } \\
2008-2012\end{array}$ \\
\hline The population in poverty & 813.196 & 575.659 & 373.137 & 402.033 & 29,2 & 35,2 & 7,7 \\
\hline Urban areas & 257.690 & 151. 811 & 150. 052 & 205. 273 & 41,1 & 1,2 & 36,8 \\
\hline Rural areas & 555.506 & 423. 848 & 223. 085 & 196. 760 & 23,7 & 47,4 & 11,8 \\
\hline
\end{tabular}

\subsection{Poverty, how sensitive the third age is?}

Referring to different studies and especially to the survey done by the Movement of Organizations Supporting Healthy Aging - MOSHA, concerning the self-perception of the poverty we have the following result:

- $\quad 17 \%$ of the elderly consider themselves as "extremely poor" and $40 \%$ as "poor" compared to $2 \%$ who consider themselves to be "in good financial situation".

- More than $33 \%$ of the elderly were identified in the informal and rural parts of the country that receive no pension at all (it's worth mentioning that the pensions in the village "the farmers pension" is considerably lower than the one in the cities").

- $16 \%$ of the participants did not have water supply system in their homes or their apartments. Nevertheless there were big differences between the zones: in informal zones in Tirana the percentage can go up to 28\%, whereas in rural zones the proportion of the elderly without access to water supply system was $35 \%$. 
- Same inequality goes for the access a toilet (WC) inside the house/apartments, with $100 \%$ in urban zones compared with only $66 \%$ in informal and rural zones.

- Around $27 \%$ of the elderly in urban zones, $25 \%$ in informal zones and $34 \%$ in rural zones did report that they did not have heat in their homes in the wintertime.

- The electricity was available for $94 \%$ of homes/apartments where the elderly live ( $99 \%$ in urban zones, $87 \%$ in informal zones of Tirana and $88 \%$ in rural zones).

- Something less than (11\%) reported that they did not have a TV (no significant difference among the above mentioned categories).

Knowing that the most of the elderly are not able to work (adding the discrimination that is done upon them, where because of the age, even though they might be well qualified and able no jobs are available for them), the only financial resource that they have is a pension.

In Albania the number of the elderly who receive a age based pension is 303. 100 in cities and 57.068 get the pension for their disabilities also in the cities, and 48. 053 in urban zones. In the rural parts there are 136. 828 who benefit from the age based pension, and 30. 205 people get pensions from specific programs such military, miners, professors, ex-workers of military industry/pilots/marines. In total there are 591.600 people who receive pensions.

After the last raise of the pensions that took place on $1^{\text {st }}$ of August 2013, the minimal pension in the cities will be 12. 024 lek per month, whereas in the rural parts it will be 8.233 lek per month, while the maximum monthly pension in the cities might reach 24. 048 lek and in the rural parts might reach 12. 140 lek. On the total, after this raise, the minimal full pension will not be less than 14. 174 lek per month; the minimal full pension in the rural parts cannot be less than 9 . 123 lek per month; and the maximal full pension in the cities will be 24.548 lek per month (source: ISSH).

Referring to the numbers above, the difference between the rural parts pensions and city pensions is quite visible. This situation can be justified in few cases because the rural parts pension beneficiaries (known mostly as farmers) own land which they can use to produce extra income, but of course this is hardly true when we talk about the third age which being that physically it is not always possible for them to work on the field, nonetheless they have the full right that they receive decent benefits for the hard work that they did all their lives.

\section{Conclusions}

This article analyzes trends in poverty in Albania. The study arrives in two main conclusions. First, due to the global financial crisis and economic growth slowdown, there was an overall increase in poverty, which constitutes a challenge for the reform of social protection scheme for our country. Second, it appears that older women face to more difficulties due to gender policies not right to social protection scheme.

Firstly, due to the global financial crisis and economic slowdown, there was an overall increase in poverty. Secondly, poverty is not just a rural issue. There has been a shift of poverty from rural to urban areas, where the latter has been a large increase in poverty. This may have been due to more concentrated efforts towards rural development, while population movements may have moved from rural to urban areas and the consequences of the crisis have affected mainly urban areas. Further efforts are needed to bring poverty to lower levels. More detailed data will shed light on regions and areas where poverty is concentrated and where interventions should therefore initially. The phenomenon of urban poverty should be examined in depth in further analysis in a future closer to understanding the causes and change in monetary poverty.

Secondly, even that Albania, is in the process of reforming social services, in a way, has made progress in performance in the legislative adjustment in terms of gender equality perspective and social policies, there is still room for improvement when it comes to gender equality in the third age. It is worth mentioning here legally protection cases identified as constituting a violation of the employment identification without underwrote older women as caregivers in the family, babysitters, cleaning the family.

To achieve legislative harmonization and social services Albania has implemented standards of service for the elderly, which serve as the basic instrument for ensuring and measuring the quality of services and guaranteeing the exercise of the rights of the elderly in accordance with the Albanian Constitution, Declaration political and International Plan of Action on Ageing, Madrid 2002 European Social Charter (revised) and the Council of Europe recommendations. Applying these standards by establishing rules for the quality of services, are required to be implemented by all providers of services in public institutions and services raised by non-profit organizations (NGOs) and other private providers.

Meanwhile, the growth of the population over 65 years old should draw the attention of state social policy making proactive and prudent pension schemes. Local authorities showing sensitivity towards the elderly, mostly female category 
where the level of jetgjatësisë for them is higher, can develop and implement through social projects and awareness campaigns or new employment opportunities in order to avoid legal violations occur; as undeclared employment; but they themselves feel more valued against their families but also from civil society. Third Age is part of society and therefore should be treated equal as everyone else, even their contribution and experience to be evaluated more in society

\section{References}

Help Age International, February 2008. Out of the Shadows

INSTAT 2010 "Femra dhe Meshkuj 2008"

INSTAT 2010 "Shqipëria në Shifra 2010"

INSTAT, "Projeksionet e popullsisë për Shqipëri 2001-2021"

INSTAT, "Trendi i varferise 2012" (www. instat. gov. almedia206688shqiperi-trendi_i_varferise_2012_. pdf)

Instituti i Sigurimeve Shoqërore 2013, Njoftim: Rritja e pensioneve nga data 1 gusht 2013

Ligji për barazinë gjinore Nr. 9970 dt. 24. 07. 2008

MPCSSHB, Mars 2011, Strategjia Kombëtare për Barazinë Gjinore dhe Reduktimin e Dhunës me Bazë Gjinore.

Nicholas Moussis, "Access to European Union law, economics, policies" (http: //www. europedia. moussis. eu/books/Book_2/5/13/05/ $03 / ?$ all=1)

Rrjeti Shqiptar për Moshim të Shëndetshëm (Movement of Organisations Supporting a Healthy Ageing - MOSHA), 2008

SEELS NETWORK (Laweyrs of Europe) November 2012, Legal Perspectives of Gender Equality in South East Europe, SKOPJE

Seksioni për Popullsinë në Departamentin e Ekonomisë dhe Cështjeve Sociale te Sekretariatit të Kombeve të Bashkuara, Projeksione të Popullsisë Botërore: (http: /lesa. un. org/unpp)

Shërbimi Social Shtetëror 2014, Analiza vjetore

Shoqëria Shqiptare për të gjitha Moshat - ASAG: (http: //moshimishqiperi. wordpress. com/2012/01/13/moshimi-vleresimi-i-legjislacionitne-shqiperil)

http: //europa. eu/legislation_summaries/employment_and_social_policy/social_protection/index_en. htm

http: //www. gsdrc. org/go/topic-guides/social-protection/types-of-social-protection

http: //open. data. al/sq/lajme/lajm/id/260/titull/Popullsia-urbane-dhe-rurale-ne-vitet-1950-2050

http: //www. parlament. al/web/pub/2012_raporti_per_varferine_15415_1. pdf 